\title{
Paideusis
}

\section{Discipline, Devotion and Dissent: Jewish, Catholic, and Islamic Schooling in Canada (Graham P. McDonough, Nadeem A. Memon \& Avi I. Mintz)}

\section{Kevin McDonough}

Volume 22, Number 2, 2015

Philosophical Perspectives on Education for Well-Being

URI: https://id.erudit.org/iderudit/1071458ar

DOI: https://doi.org/10.7202/1071458ar

See table of contents

Publisher(s)

Canadian Philosophy of Education Society

ISSN

0838-4517 (print)

1916-0348 (digital)

Explore this journal

Cite this review

McDonough, K. (2015). Review of [Discipline, Devotion and Dissent: Jewish, Catholic, and Islamic Schooling in Canada (Graham P. McDonough, Nadeem A. Memon \& Avi I. Mintz)]. Paideusis, 22(2), 50-55.

https://doi.org/10.7202/1071458ar 
Paideusis, Volume 22 (2015), No. 2, pp. 50-55

Review of

\title{
Discipline, Devotion, and Dissent: Jewish, Catholic, and Islamic Schooling in Canada
}

\author{
Edited by Graham P. McDonough, Nadeem A. Memon, and Avi I. Mintz, Waterloo: Wilfred \\ Laurier University Press, 2013
}

\section{KEVIN MCDONOUGH \\ McGill University}

Discipline, Devotion, and Dissent: Jewish, Catholic, and Islamic Schooling in Canada aims to shed light on the place of faith-based schools in a liberal-democratic society. Individually, the essays in this volume represent a series of qualitative descriptions or case studies of religious schooling. Collectively, they provide an empirical snapshot of a particular local context that should interest philosophers of education within and beyond Canadian borders. More specifically, the eleven essays that make up the volume describe, and to some extent defend, a view of faith-based schooling that is professedly compatible with the aims of liberal-democratic citizenship education traditionally associated with common schools. Accordingly, as the editors note in their helpful introductory essay, the volume as a whole largely avoids discussion of indoctrinatory and "isolationist" forms of religious schooling, whose educational missions clash with and perhaps even explicitly reject the educational values associated with secular, liberal-democratic citizenship (p. 9). In short, religious schooling in this volume is intentionally selective- portraying faith schools as engaged with and supportive of values such as religious pluralism, critical thinking, social integration, and participation in the political community beyond the confines of a particular religious tradition.

My aims in this brief review are two: first, to provide a representative account of significant issues raised in several chapters; second, to highlight some key connections to contemporary philosophical debates about the role of faith-based schools in liberal-democratic societies. I apologize in advance for neglecting several very strong essays in the volume-most notably, the chapters by Donlevy and McDonough. Both of these essays, along with Mintz's synthetic concluding chapter, are worthy of a careful reading by those interested in the topic of faith-based schools, religious education, and democratic citizenship. Regarding the chapters that I do discuss in some detail below, I express several reservations about the various claims advanced in the book regarding the compatibility of religious schooling and citizenship education in a secular, pluralistic, democratic society.

Aside from the introduction by the volume's editors and the concluding essay by Mintz, both of which provide helpful context and astute analysis, the main body of the book is divided into three main parts. Each part contains three essays_one each focusing on Jewish, Catholic, and Islamic schools respectively.

Part A is titled "Aims and Practices." In Chapter 1, Seymour Epstein emphasizes what he sees as the diverse range of Jewish day schools, though as I shall argue below his claims about diversity are perhaps somewhat overstated and thus potentially misleading. Epstein categorizes the curricular and pedagogical differences of seventy-four Jewish day schools according to a six-part scheme (p. 28) corresponding to different ideological and denominational distinctions within Judaism-from 
interdenominational "community schools," which may have a particular educational focus (e.g. arts-based), at one end of the spectrum, to Orthodox and fervently Orthodox schools at the other end of the spectrum.

In Chapter 2, Mario D'Souza concentrates on outlining a distinctive and "universal philosophy of Catholic education," which supposedly underscores the whole range of diverse Catholic schools in Canadian society. At the center of D'Souza's articulation of this "perfectionist" Catholic vision of education is its humanizing and liberating aspects (p. 55). As he puts it, "the primary aim of Catholic education is the promotion of human freedom through growth in one's personhood" (p. 50).

In Chapter 3, Nadeem A. Memon provides an informative sketch of what is still the relatively young history of Islamic schooling in Canada (mostly concentrated in a few major urban centers) and a brief account of what he terms a "general consensus" on the philosophical foundations (i.e. "aims") of Islamic education. Most importantly, though, Memon outlines a rich account of the tensions and conflicts that arise between, on the one hand, the epistemic, spiritual, and ethical aspirations associated with that foundation, and on the other hand, the highly politicized forces that shape Islamic schooling. These reflections are, furthermore, embedded within a thoughtful understanding of the various global (Islamization), continental (i.e. effects from the US on Canadian trends), and local (intra-Canadian) forces that are shaping the development of Islamic schooling in Canada.

Together, the three essays in Part A sketch a picture of religious schooling in Canada that underlines the complexity and diversity of aims and practices. Nevertheless, the various authors agree that, at least in many "real-world" cases, faith-based schooling is compatible with, and perhaps even serves to strengthen, secular values associated with democratic citizenship. One problem that arises in assessing such claims is the fact that there is no available consensus on the core features of "secular democratic citizenship." For example, at different points in the volume, secular or "civic" values are taken to be associated with concerns about "social cohesion," "personal autonomy," and participation in civic and political life. Accordingly, the job of resolving disputes about the extent to which faith-based schooling coheres with secular, democratic educational aims is impeded by the absence of a well-defined and consistent measure of coherence.

This absence of consensus about the character of democratic citizenship is further reflected in the essays in Part B, "Faith and Citizenship," which together take up more directly questions about the relationship between the aims and practices of faith-based schooling, on the one hand, and broader educational interests of the larger, pluralistic society, on the other hand. Former teachers, who provide case study analyses of faith-based schools in which they taught, author two of the essays in this section.

In Chapter 4, Greg Beiles describes the civics curriculum at an interdenominational day school in Toronto, in order to illustrate his claim that faith-based education is compatible with the civic educational goals of liberal-democracy. The chapter provides an interesting case study of this school, but its broader conclusions are not entirely convincing. In order to establish a framework for democratic citizenship education upon which to ground his analysis, Beiles appeals to the philosopher of education Walter Feinberg, whose conception of democratic citizenship education incorporates a strong theoretical requirement of personal autonomy - the capacity for radical critical reflection on the values and religious rituals and traditions associated with one's "primary" community of upbringing. While Beiles' description of a pluralistic set of educational practices in Toronto Heschel School clearly illustrates the aspiration to teach students to think reflectively within a religiously pluralistic framework, it's far from clear that the scope of pluralism permitted within the school is compatible with the kind of skills and capacities that democratic theorists like Feinberg (and many others) believe are prerequisites for an adequate citizenship education. For example, Beiles' account emphasizes the school's "intradenominational pluralism" - the plurality of perspectives and interpretations offered within Jewish religious culture. By contrast, democratic citizenship education, at least as Feinberg understands it, requires opportunities for interdenominational engagement. The difference is not merely academic. An education that confines interpretive pluralism within a single religious tradition can 
foreclose rather than promote opportunities for the kind of critical required for democratic citizenship. According to liberal-democratic theorists like Feinberg, democratic deliberation requires opportunities to test basic assumptions about one's inherited religious commitments, and about the value of religious commitment itself. However, intradenominational interpretive pluralism cannot by itself guarantee such opportunities. Thus, if faith schools require students to accept, as a prerequisite to any further critical thinking, the existence of a single God who is a non-physical, infinite being (p. 117, then the education provided therein seems sharply incompatible with democratic citizenship education in the sense that liberal-democratic theorists like Feinberg intend.

Consider the following example to illustrate this argument. At one point in the chapter, Beiles describes a grade seven Ancient Civilization course that, he says, fosters an appreciation of the fact that "Jews expressed multiple responses to the same historical event[s]" (110). But an education that teaches students to recognize plurality within one's primary religious community is not the same thing as an education that teaches them to recognize the contingency of that tradition in relation to alternative traditions and communities. It's thus unclear whether the education provided in even a very liberal and relatively open faith-based school like the one Beiles depicts can justifiably claim to meet the demand that civic education enable students to recognize a significant degree of "contingency of their own traditions" (p. 109). As such, there is room to doubt Beiles' central claim that the civics curriculum at his school is compatible with the kind of liberal-democratic conception of citizenship forwarded by many educational theorists, including those Beiles appeals to.

Asma Ahmed's contribution to the volume in Chapter 6 also develops a case study of a particular faith-based school in Ontario-in this case the London Islamic School. Ahmed is committed to show that LIS provides an education that reinforces a "responsible Muslim identity," and that this aim is compatible with the values and principles of liberal-democratic citizenship in "the modern West" (p. 159). Like Beiles, Ahmed provides helpful and interesting descriptions of in-school practices, making concrete the kind of curricula and pedagogy that characterize this particular Islamic school. In this respect, both essays make an important contribution in combatting and complicating prevalent social stereotypes, which are likely to preemptively cast suspicion on the educational mission of such schools.

Also like Beiles, Ahmed's essay raises a number of questions and unresolved issues with which philosophers of education can productively engage. One such question has to do with education's role as an agent of integration and social cohesion. According to Ahmed, the mission of LIS takes for granted the educational role of reinforcing and, indeed, imposing a "robust Canadian Muslim identity." It would seem, in Ahmed's account, that the alternatives to such a "hybrid identity" approach are basically two: either a narrow-minded, singular religious identity or an alienating and unattractive "assimilation" to the secular dominant culture of Canadian society. This particular background highlights the appeal of Ahmed's preferred alternative, which also happens to be the one she associates with the educational mission of LIS. However, while Ahmed approvingly quotes Tariq Ramadan's invocation of educational "milestones which should permit them [students] to find, consciously and freely, their own way," (p. 146) she does not consider the possibility that for some students such freedom may take them in a radically different direction from the assumed goal of "how to be and remain Muslim."

Further consideration of this question might productively engage further, for example, with Ramadan's notion of a "post-integration" stage of educational achievement in which students develop skills associated with the project of social transformation. As this is explicitly a project not just of reinforcing and strengthening a particular religious identity, but also one that aims to reshape the broader public sphere within which multiple religious and non-religious identities interact in a pluralist society, one hoped-for result should certainly be the transformation of the secular public sphere in ways that render it more welcoming and hospitable to stigmatized and disadvantaged minorities, including Muslims. However, if successful, such an educational project might significantly diminish the external social pressures and stigmas that create the need Ahmed posits for an education that reproduces a positive and "robust" religious identity in the first place. 
I am suggesting here that a more in-depth engagement with Ramadan's notion of "post-integration" education could form part of a larger political strategy for social integration that creates alternative pathways to citizenship, some of which lead away from religious identity and affiliation for at least some students. To some extent, of course, such speculations are empirical rather than philosophical. Nevertheless, they converge with philosophical questions insofar as the presumed spectrum of educational aims (and corresponding policies and practices) between "integration" (which is presumed to be compatible with a permanent and unquestioned loyalty to one's primary faith group) and assimilation (which is presumed to be incompatible) is perhaps not as clearly predefined as it initially appears. Philosophers of education could presumably play a central role both in clarifying the conceptual space associated with a post-integrationist educational project and in evaluating the relative merits of alternative educational proposals for advancing (or critiquing) such a project.

The themes addressed in Part C of the volume extend those addressed in Part B by focusing on how some faith-based schools "view and respond to dissent" (p. 14). In Chapter 9, Qaiser Ahmad develops the view that some Islamic schools confound philosophical distinctions designed to guide state educational policy in a liberal-democratic society. Ahmad, who also writes partly from his perspective as a former teacher in an Ontario faith-based school, challenges the distinction between "moderate" and "strong" identity schools which has been forwarded and applied in recent years by several philosophers of education. From this perspective, "strong" religious schools are those whose educational mission instils a permanent religious identity by providing a religiously isolationist and homogenizing education. "Moderate" religious schools, by contrast, tilt the educational playing field by favoring a particular religious perspective as an enabling condition for students' identity formation, but they permit and encourage engagement with alternative religious perspectives, and thus facilitate critical reflection upon one's primary religious tradition.

In this respect, it's not clear how we should make sense of Ahmad's claim that the Islamic school at which he taught "met some of the criteria of strong schools but also some of the criteria of moderate schools" (p. 219). In support of this claim, he notes that, "Our goal at the school was to ensure that our students neither became insular nor lost their faith when they entered society" (p. 219). Part of the difficulty in interpreting and evaluating Ahmad's main claim about Islamic schooling lies in the conceptual coarseness of terms like religious "insularity" and "isolation." Is the Islamic school he describes more insular than he lets on in his description? In order to evaluate this claim, we'd need to know not merely whether the school permits or encourages engagement with alternative religious perspectives. We'd also need to know more than Ahmad's account provides about the degree of self-criticality permitted (or not) in the school's various practices. However, considering that the school remains committed to ensuring that the education it provides means "that students would not willfully change Islamic practice, and would respectfully challenge those who believe Islam needs to be transformed," there seem to be clear reasons from Ahmad's own account to support the conclusion that this particular Islamic school falls clearly on one side of the strong/moderate divide.

Chapter 7 by Pomson and Schnoor highlights the numerous social factors that have contributed to the alteration and transformation of Jewish religious schools in Toronto. They focus specifically on a set of developments that they argue have shaped a relatively new phenomenon whereby urban, liberal, secular Jewish parents have abandoned their traditional advocacy of public schooling's civic benefits in favor of private, non-Orthodox, religious day schools (p. 172). The chapter itself focuses on a case study of a small K-8 private school—the Downtown Jewish Day School (DJDS).

One of the most interesting features of Pomson and Schnoor's account of DJDS, especially in light of the question of how religious schooling may be made compatible with the aims of democratic civic education, emerges in their discussion of what they call the "instability" surrounding the school's initial formation and its maintenance in its early years of operation. They highlight several factors that create instability and conflict in the school context-factors that bear directly on the question of whether the schooling DJDS provides is compatible with the aims of democratic citizenship education. For example, one such factor is the conflicting backgrounds of parents and teachers at the school. 
Parents are described as urbanites who have rejected the materialism of suburban life; they are religious non-conformists who have often rejected their parents' favored way of life, and many of them have married outside the faith, but are "raising their children as Jews" (p. 174, 182). By contrast, teachers are portrayed as "uptown" suburbanites whose educational values conflict with the "progressive" educational values favored by parents (p. 181). A second source of instability in the school is the varied and diverse backgrounds of parents themselves, which create frequent disagreements and tensions in determining the school's educational direction. In one particularly sharp disagreement, a gay member of the school community objected to a pre-Chanukah event sponsored by the school which was to be led by a Rabbi perceived to be hostile to certain minority groups within the school.

Pomson and Schnoor's detailed discussion of these and other sources of instability and conflict (or "points of collision") within the school community provides a source for much potentially useful reflection on the part of educational philosophers. In the context of earlier points raised in this brief review, the important upshot is that DJDS seems to constitute a school community that provides clear opportunities for students to witness and even learn about the "contingency" of their tradition in relation to alternative religious and ethical traditions. For example, the conflicting ethical and religious views that characterize debates at DJDS go well beyond the teachings about pluralism in the Jewish tradition described by Beiles. Furthermore, there is no sense that instilling a strong and irrevocable "comprehensive" religious faith is among the goals of the school, as it is in the case of Ahmad's account of her Islamic school. As such, it may seem that of the various case studies of faith-based schooling discussed in this volume, the DJDS provides perhaps the clearest illustration of the potential compatibility of religious schools with secular democratic citizenship education.

An important question remains, however, as to how much, and how well, these deep differences translate into circumstances that encourage an education in democratic citizenship. While Pomson and Schnoor's case study certainly illustrates the fact that not all faith-based schools value obedience and conformity to (religious) authority, it is less clear that even more liberal and progressive-minded school communities provide favorable contexts for the development of citizenship skills like "critical dialogue." After all, conflict and disagreement do not themselves ensure outcomes like mutual respect and recognition across deep differences. Nevertheless, to the extent that such conflicts are incorporated into the "day-to-day" life of the school, and to the extent that they reflect a broad-based commitment to sustaining a pluralistic school community and a commitment to harmonious conflict resolution, the DJDS case provides a useful illustration and reference point for those who see faith-based schools as potentially valuable vehicles for citizenship education in democratic societies.

Aside from criticisms of individual chapters, Discipline, Devotion, and Dissent as a whole contains a couple of noteworthy limitations. First, for a volume that proposes to shine a light on the diversity of aims and practices that characterize faith-based schooling in Canada, the focus is somewhat narrower than one might hope, in a couple of respects. Case studies of particular schools are heavily slanted toward urban Ontario; those looking for accounts of faith-based schools in Alberta and Quebec-educational contexts that differ enormously from each other and from Ontario-will not find them in this volume. This, of course, raises doubts about just how representative the collection as a whole is of its stated object of study.

Second, the analyses and discussion in various chapters of the volume focus overwhelmingly on relatively liberal and open forms of faith-based schooling while downplaying or deemphasizing the significance of stronger, more Orthodox forms. From one perspective, this is not a criticism but an intended feature since the volume aims to combat stereotypes about rigid, indoctrinatory forms of religious schooling that are presumably ill-suited for, if not strongly incompatible with, educational aims associated with democratic citizenship. From another perspective, however, several chapters in this volume risk reinforcing an opposite, and perhaps increasingly common, misunderstanding that faith-based schools whose aims nominally include pluralism and mutual respect are therefore benign from the perspective of liberal-democratic citizenship education.

The preceding criticisms and limitations are not meant to discourage readers from consulting 
Discipline, Devotion, and Dissent as a scholarly resource. Indeed, I strongly recommend it for those interested in debates about the place of faith-based schools in Canada and beyond. In particular, philosophers of education who take seriously the need to supplement philosophical analysis with empirically-informed research on religious schooling would benefit from reading the richly detailed and articulate essays that make up this book. 